\title{
Considerações jurídicas, éticas e médico-legais sobre a reprodução post mortem em alguns países da Ibero-América: revisão integrativa*
}

\author{
Jorge Armando Guzmán Lozano - Juliana Takitane $^{\mathbf{b}}$
}

\begin{abstract}
Resumo: A aplicação das técnicas de reprodução humana assistida após a morte de um dos genitores é uma realidade que vai ganhando relevância e apoio entre juízes e doutrinários, mas que ainda encontra uma ampla rejeição social, principalmente em face dos sérios conflitos morais, éticos e religiosos. Vários países da região vêm discutindo a adaptação de suas leis diante do crescimento da casuística. Neste estudo, é realizada uma análise comparativa da esfera jurídica, ética e médico-legal dos países ibero-americanos, por meio de uma revisão integrativa. Foram recuperados 21 estudos primários que abordam a situação normativa da Argentina, do Brasil, da Colômbia, da Espanha, do Peru, de Portugal e do Uruguai. Do conjunto, unicamente o Uruguai e a Espanha têm normatização permissiva para a reprodução post mortem. O primeiro de forma expressa e o último de forma implícita. A legislação de Portugal é proibitiva para a maioria das técnicas, à exceção da transferência póstuma de embriões. A Argentina, a Colômbia e o Peru estão desregulamentados. O Brasil encontra-se numa situação especial, pois, embora inexista regulamentação específica, debate-se o caráter vinculante de algumas normativas. Ainda, é discutido o papel da medicina legal ante os novos desafios bioéticos e biojurídicos, em termos práticos e teóricos, propondo uma participação no debate que antecede toda possível autorização.
\end{abstract}

Palavras-chave: reprodução póstuma; legislação e jurisprudência; bioética; América Latina; Espanha; Portugal

* Artigo de pesquisa.

a Mestre em Ética Biomédica. Especialista em Medicina Legal e Perícias Médicas. Médico. Departamento de Medicina Legal, Ética Médica e Medicina Social e do Trabalho da Faculdade de Medicina da Universidade de São Paulo, Brasil.

Correio eletrônico: jorgeguzmanlozano@uca.edu.ar ORCID: https://orcid.org/0000-0002-5425-6082

b Doutora e mestra em Ciências. Especialista em Histopatologia e Biologia Forense. Graduada em Ciências Biológicas. Departamento de Medicina Legal, Ética Médica e Medicina Social e do Trabalho da Faculdade de Medicina da Universidade de São Paulo, Brasil.

Correio eletrônico: juliana.takitane@hc.fm.usp.br ORCID: https://orcid.org/0000-0002-4581-7685 
Recebido: 27/04/2020 Aprovado: 09/12/2020

Disponível on-line: 23/07/2021

Para citar: Guzmán Lozano JA, Takitane J. Considerações jurídicas, éticas e médico-legais sobre a reprodução post mortem em alguns países da Ibero-América: revisão integrativa. Rev. latinoam. bioet [Internet]. $23^{\circ}$ de julho de 2021 [citado $23^{\circ}$ de julho de 2021];21(1):11-30. Disponível em: https://revistas.unimilitar.edu.co/index.php/rlbi/article/view/4758

\title{
Legal, Ethical and Medical Considerations about Post-mortem Reproduction in some Countries of Ibero-America: Integrative Review
}

\begin{abstract}
The application of assisted human reproduction techniques after the death of one of the genitors is a reality that has gained relevance and support among judges and doctrinaires, although it still finds a wide social rejection, mainly in the face of serious moral, ethical and religious conflicts. Several countries in the region have discussed adapting their laws to the growth of casuistry. In the study, a comparative analysis of the legal, ethical and medical sphere of ibero-American countries is carried out through an integrative review. 21 primary studies were obtained addressing the regulatory situation in Argentina, Brazil, Colombia, Spain, Peru, Portugal and Uruguay. From these countries, only Uruguay and Spain have permissive regulation for post-mortem reproduction. The first, expressly and the last implicitly. Portugal's legislation is prohibitive for most techniques, with the exception of the posthumous transfer of embryos. Argentina, Colombia and Peru are not regulated. Brazil is in a special situation, as, there is no specific regulation, the binding nature of some regulations is discussed. Finally, the role of legal medicine has been discussed in the face of new bioethical and biolegal challenges, in practical and theoretical terms, posing participation in the debate that precedes any possible authorization.
\end{abstract}

Keywords: posthumous reproduction; legislation and jurisprudence; bioethics; Latin America; Spain; Portugal

\section{Consideraciones jurídicas, éticas y medicolegales acerca de la reproducción post mortem en algunos países de la Iberoamérica: revisión integrativa}

Resumen: La aplicación de las técnicas de reproducción humana asistida tras la muerte de uno de los genitores es una realidad que ha cobrado relevancia y apoyo entre jueces y doctrinarios, pero que aún encuentra amplio rechazo social, principalmente en cara a los serios conflictos morales, éticos y religiosos. Varios países de la región han discutido la adaptación de sus leyes ante el crecimiento de la casuística. En el estudio, se realiza un análisis comparativo de la esfera jurídica, ética y medicolegal de los países iberoamericanos, por medio de una revisión integrativa. Se rescataron 21 estudios primarios que abordan la situación normativa de Argentina, Brasil, Colombia, España, Perú, Portugal y Uruguay. De estos, únicamente Uruguay y España tienen regulación permisiva para la reproducción post mortem. El primero de forma expresa y el último de forma implícita. La legislación de Portugal es prohibitiva para la mayoría de las técnicas, a excepción de la transferencia póstuma de embriones. Argentina, Colombina y Perú están desregularizados. Brasil se encuentra en una situación especial, pues, aunque inexista regulación específica, se debate el carácter vinculante de algunas normativas. Por último, se ha discutido el rol de la medicina legal ante los nuevos desafíos bioéticos y biojurídicos, en términos prácticos y teóricos, planteando una participación en el debate que antecede toda posible autorización.

Palabras clave: reproducción póstuma; legislación y jurisprudencia; bioética; América Latina; España; Portugal 


\section{Introdução}

As técnicas de reprodução humana assistida (TRHA) evoluíram nas últimas décadas de maneira vertiginosa. Os avanços originalmente pensados no contexto da infertilidade têm se expandido para novas áreas na tentativa de cobrir, ou gerar, inéditas necessidades sociais. Nesse diapasão, a outrora impensada reprodução além da vida tornou-se tecnicamente possível, juridicamente cabível e moralmente questionável. Trata-se da aplicação das TRHA após a morte de um dos titulares do material genético. $\mathrm{O}$ estabelecimento desse controvertido vínculo entre a vida, a morte e a reprodução só foi possível por meio do aperfeiçoamento da criopreservação de gametas e embriões (1). As possibilidades técnicas da reprodução post mortem podem ser enquadradas, num sentido geral, nos seguintes tópicos: 1) uso de material genético criopreservado antes da morte do titular; 2) extração de material genético de cadáver para o uso em fertilização assistida; 3) transferência de embriões criopreservados gerados com material genético do de cujus.

O uso de óvulos da mulher falecida - para fins de reprodução póstuma - ainda é ínfimo, se comparado com a solicitação de uso de sêmen do homem falecido (2). Tendo em vista tais circunspecções, a nossa pesquisa se concentra nas modalidades casuisticamente mais significativas.

A preservação do material genético, em grande parte, envolve homens que se submeterão a quimioterapias, em que existe risco de comprometimento de sua fertilidade, ou pessoas que trabalham em condições adversas (insalubridade, conflito armado, profissões com alto índice de periculosidade). $\mathrm{O}$ conflito surge quando o homem (titular) falece sem ter manifestado seu consentimento para o uso post mortem do material depositado. Nesse caso, a viúva ou a companheira reclama a utilização do material - para TRHA post mortem - , alegando a existência de um projeto procriacional interrompido.

Por sua vez, a solicitação de extração de sêmen post mortem (ESP), aos poucos, está deixando de ser uma prática incomum. Apresenta-se quando o homem falece de maneira repentina sem ter iniciado TRHA, e a viúva ou a companheira requer que seja feita a extração compulsória do material genético do cadáver. Nos países onde a técnica é autorizada, a extração se realiza em até 36 horas após o óbito (3), por meio de eletroejaculação, aspiração microcirúrgica de espermatozoides do epidídimo, biopsia testicular ou remoção do testículo em bloco (4).

Uma situação muito delicada se dá quando o casal inicia TRHA, mas o homem vem a falecer deixando embriões congelados - gerados a partir de seu material genético - à espera de serem implantados. Dada a circunstância, a viúva ou a companheira requer por via judicial que os embriões sejam transferidos (implantados) nela, configurando uma solicitação de transferência embrionária post mortem. Desse modo, ao conflito ético-jurídico que supõe a reprodução póstuma, agrega-se a discussão sobre o estatuto jurídico do embrião humano.

Em linhas gerais, o caráter conflitivo e dilemático depende dos seguintes pontos: 1) existência ou ausência de consentimento expresso, prévio e escrito; 2) marco normativo vigente para a realização de TRHA post mortem; 3) análise prévia sobre a pertinência moral das técnicas.

Entre os casos ditos "emblemáticos", tanto pelo ineditismo como pela repercussão mediática e acadêmica, temos a primeira autorização de inseminação post mortem - o caso Parpelaix - na França, em 1984 (1); o primeiro caso exitoso de concepção póstuma - o caso Blood - no Reino Unido, em 1997 (5); a primeira concepção por injeção intracitoplasmática de espermatozoides (ICSI) com esperma coletado 30 horas após a morte do titular - o caso Vernoff - nos Estados Unidos, em 1999 (4), entre outros. Gradativamente, houve um aumento na demanda por esse procedimento no mundo inteiro. Os países anglo-saxônicos e centro-europeus reagiram de formas diversas, já seja optando pela estrita proibição da técnica, seja pela autorização (livre ou condicionada). Países como França, Alemanha, Suécia ou Canadá proíbem esses procedimentos; já no Reino Unido é permitido desde que o consentimento paterno pré-mortem seja registrado (6). Entre os episódios de relevância na região ibero-americana, temos uma autorização judicial de ESP - o caso da viúva espanhola - na Argentina, em 1999 (7); a primeira reprodução post mortem autorizada pelo judiciário no Brasil 
- o caso Lenerneier —, em 2010 (8); o indeferimento de pedido de fertilização póstuma por ausência de consentimento expresso - o caso "B-Lisboa" em Portugal, em 2013 (9), entre outros.

A maior parte das legislações ficou em franca assincronia com as novas possibilidades filiatórias e/ou sucessórias decorrentes da reprodução além da vida. Isso deu lugar ao surgimento de alguns paradoxos tais como filhos biológicos, mas sem filiação com o de cujus, ou filhos póstumos reconhecidos - juridicamente -, mas sem direito à herança. Por sua vez, pontos-chave como a autonomia nas decisões reprodutivas, o bem-estar do menor, o direito à biparentalidade ou o respeito à dignidade corpórea do falecido atiçam o debate bioético sobre a legitimidade das TRHA post mortem $(10,11)$. Nesse diapasão, fica claro que o estabelecimento dos pontos de atrito depende, uma vez mais, das múltiplas combinações possíveis: da técnica, do pedido, do tipo e da origem do material, dos princípios e dos valores envolvidos etc.

Conhecer o panorama da temática na Ibero-América resulta altamente construtivo para o cenário atual, a julgar pela expansão da casuística e a anfractuosa evolução das leis na região. A mudança nas prioridades bioéticas, biopolíticas, biossociais e biojurídicas dependem de uma enorme e instável quantidade de fatores; não obstante, cabe aos estudiosos da medicina legal, da bioética ou do biodireito antecipar-se, na medida do possível, aos adventos da medicina pós-moderna por meio do compartilhamento das experiências forâneas ou na reflexão crítica dos dilemas domésticos, aqueles que ainda driblam a exígua regulamentação vigente.

\section{Objetivos}

Identificar e categorizar as legislações dos países ibero-americanos da amostra, de acordo com a permissibilidade das técnicas de reprodução post mortem. Integrar à análise os principais questionamentos éticos e médico-legais que trazem consigo as técnicas de reprodução post mortem.

\section{Métodos}

A presente revisão integrativa foi elaborada com base nas seguintes etapas, segundo o modelo de
Ganong (12): 1) identificação da questão da pesquisa; 2) amostragem; 3) categorização dos estudos; 4) avaliação dos estudos incluídos; 5) interpretação dos resultados; 6) síntese de conhecimento. Para atender aos objetivos do estudo, definiu-se a questão orientadora: qual é o panorama ético-legal sobre a fecundação post mortem na Ibero-América? As bases de dados utilizadas foram scielo, PubMed, Dialnet, ScienceDirect, DoAJ, Lilacs e Google Scholar. A busca foi realizada com o uso de descritores controlados e selecionados no Medical Subject

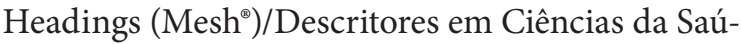
de (Decs $)^{\circledast}$ : fecundação; reprodução póstuma; concepção póstuma; fertilização in vitro; post mortem; legislação e jurisprudência; ética; bioética; América Latina; Espanha; Portugal (e suas traduções a inglês e espanhol). Para o refinamento da busca, foram utilizadas palavras-chave (keywords), tais como: filiação; sucessão; [países]. Os operadores booleanos [AND] e [OR] foram empregados de acordo com a necessidade, a fim de aprimorar a experiência de busca. Por exemplo, para a base scielo, a forma de busca adotada foi "Reprodução [AND] post mortem; reproducción [OR] inseminación [AND] post mortem [AND] países". A estratégia de busca para as outras bases seguiu um tratamento similar, destacando a combinação de descritores para atingir uma maior especificidade. Artigos que atendam ao objeto de estudo, artigos em português, espanhol e inglês, e artigos publicados entre 2010 e 2019 foram os critérios de inclusão. Artigos em outras línguas, artigos publicados antes de 2010, monografias, dissertações, teses, comunicados ou editoriais, artigos que não abordam substancialmente o objeto de estudo foram os critérios de exclusão. A seleção inicial obedeceu à leitura de títulos e resumos - ou na íntegra, quando foi necessário e ao cotejo de afinidade com a questão orientadora da pesquisa. A leitura crítica - na íntegra permitiu a categorização dos dados. A partir dos resultados, leis e regulamentações sobre o assunto foram pesquisados em sites oficiais dos países envolvidos e incluídos de forma complementar para compor o acervo final que foi analisado. Por fim, os dados foram confrontados com fontes oficiais disponíveis on-line, a fim de confirmar a sua validade, pertinência e vigência. 


\section{Resultados e discussão}

\section{Caracterização da produção}

A busca otimizada nas bases de dados contemplou um total inicial de 281 estudos. Após a leitura de títulos e resumos, e a aplicação dos critérios de inclusão e exclusão, 238 artigos foram descartados, resultando 43 artigos elegíveis. Depois da leitura na íntegra, foram excluídos 22 artigos, os duplicados, com informações insuficientes ou repetitivas, ou aqueles que não abordavam substancialmente a questão orientadora da pesquisa, resultando uma amostra final de 21 estudos (Figura 1).

O Quadro 1 mostra a distribuição dos estudos primários de acordo com autor, título/fonte, país e idioma. Para sistematizar e facilitar a citação na fase de análise, os estudos primários foram codificados da seguinte forma: Estudo $(\mathrm{E})+\mathrm{n}^{\mathrm{o}}=(\mathrm{E} 1)$.

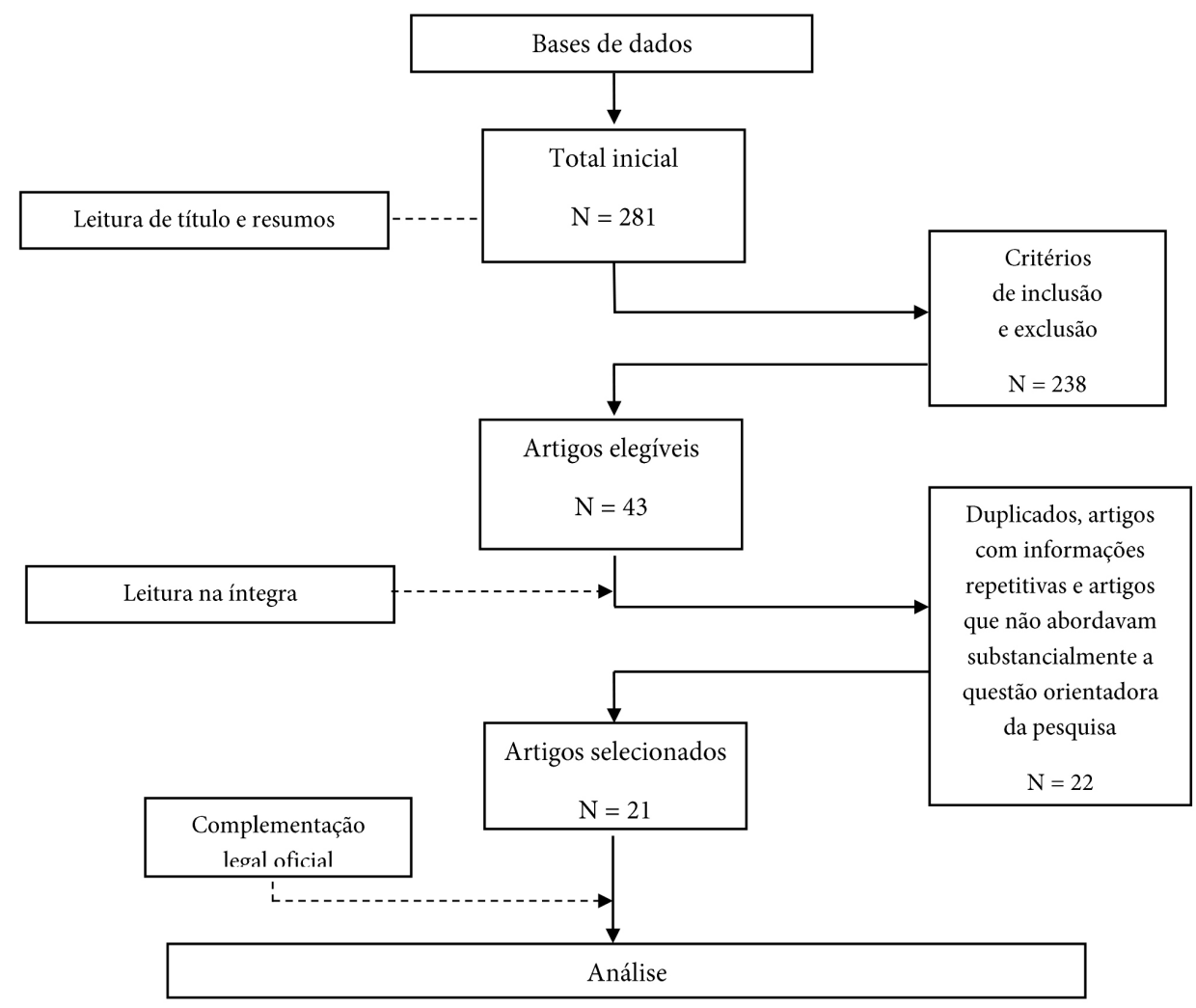

Figura 1. Fluxograma de busca

Fonte: elaboração própria, 2020. 
Quadro 1. Distribuição dos estudos de acordo com autor, título/fonte, país, idioma

\begin{tabular}{|c|c|c|c|c|}
\hline Cód./Ano & Autor & Título/Fonte & País $^{1}$ & Idioma \\
\hline $\begin{array}{l}\text { E1 } \\
2018(13)\end{array}$ & Enguer GP, Ramón FF & $\begin{array}{l}\text { Dilemas bioéticos y jurídicos de la reproducción asistida en la } \\
\text { sociedad actual en España. Revista Latinoamericana de Bioética. } \\
\text { 2018;18(1):104-35. }\end{array}$ & Espanha & Espanhol \\
\hline $\begin{array}{l}\text { E2 } \\
2017(14) \\
\end{array}$ & Ribeiro RB & $\begin{array}{l}\text { Reprodução assistida post mortem no Direito brasileiro. Revista } \\
\text { de Biodireito e Direito dos Animais. 2017;3(1):36-56. }\end{array}$ & Brasil & Português \\
\hline $\begin{array}{l}\mathrm{E3} \\
2017(15)\end{array}$ & Herrera M & $\begin{array}{l}\text { Un debate complejo: la técnica de reproducción humana asistida } \\
\text { post mortem desde la perspectiva comparada. Revista IUs. } \\
\text { 2017;11(39):185-206. }\end{array}$ & Argentina & Espanhol \\
\hline $\begin{array}{l}\text { E4 } \\
2019(16)\end{array}$ & Leite TH & $\begin{array}{l}\text { Análise crítica sobre a evolução das normas éticas para a utilização } \\
\text { das técnicas de reprodução assistida no Brasil. Ciência \& Saúde } \\
\text { Coletiva. 2019;24(3):917-28. }\end{array}$ & Brasil & Português \\
\hline
\end{tabular}

$\begin{array}{lll}\text { E5 } & \text { Oliveira NB, Sá MF } & \begin{array}{l}\text { Panorama bioético e jurídico da reprodução humana assistida no } \\ \text { Brasil. Revista de Bioética y Derecho. 2015;34:64-80. }\end{array}\end{array} \quad$ Brasil $\quad$ Português

\begin{tabular}{lll}
\hline E6 & Consentimiento presunto a las técnicas de reproducción humana \\
2019 (18) & Geri L & $\begin{array}{l}\text { asistida post mortem. Criterios para su regulación en Argentina. Argentina Espanhol } \\
\text { Revista de Bioética y Derecho. 2019;46:149-65. }\end{array}$ \\
\hline
\end{tabular}

\begin{tabular}{lllll}
\hline E7 & Rodríguez Guitián & $\begin{array}{l}\text { La reproducción artificial post mortem en España: estudio } \\
\text { ante un nuevo dilema jurídico. Iuris Tantum Revista Boliviana de } \\
\text { Derecho.2015;20:292-322. }\end{array}$ & Espanha & Espanhol \\
\hline E8 & BM & $\begin{array}{l}\text { Reproducción asistida y filiación. Tres casos. Revista Opinión } \\
\text { Jurídica. 2013;12(24):135-50. }\end{array}$ & $\begin{array}{l}\text { Espanha/ } \\
\text { Colômbia }\end{array}$ & Espanhol \\
\hline
\end{tabular}

\begin{tabular}{|c|c|c|c|c|}
\hline $\begin{array}{l}\text { E9 } \\
2017(21)\end{array}$ & Varsi Rospigliosi E & $\begin{array}{l}\text { Determinación de la filiación en la procreación asistida. Revista } \\
\text { IUS. 2017;11(39):109-37. }\end{array}$ & Peru & Espanhol \\
\hline $\begin{array}{l}\mathrm{E} 10 \\
2012(22)\end{array}$ & Dantas E, Raposo V & $\begin{array}{l}\text { Legal aspects of post-mortem reproduction: A comparative } \\
\text { perspective of French, Brazilian and Portuguese legal systems. } \\
\text { Medicine and Law. 2012;31(2):181-98. }\end{array}$ & $\begin{array}{l}\text { Brasil/ } \\
\text { Portugal }\end{array}$ & Inglés \\
\hline $\begin{array}{l}\text { E11 } \\
2014(23)\end{array}$ & Abreu CS et al. & $\begin{array}{l}\text { Estudo das regulamentações de reprodução humana assistida no } \\
\text { Brasil, Chile, Uruguai e na Argentina. Reprodução \& Climatério. } \\
\text { 2014;29(1):27-31. }\end{array}$ & $\begin{array}{l}\text { Brasil/ } \\
\text { Chile/ } \\
\text { Uruguai/ } \\
\text { Argentina }\end{array}$ & Português \\
\hline $\begin{array}{l}\mathrm{E} 12 \\
2017(24)\end{array}$ & Krasnow AN & $\begin{array}{l}\text { La filiación por técnicas de reproducción humana asistida en } \\
\text { el Código Civil y Comercial argentino. Un avance que permite } \\
\text { armonizar la norma con la realidad. Revista de Derecho Privado. } \\
\text { 2017;32(1):175-217. }\end{array}$ & Argentina & Espanhol \\
\hline $\begin{array}{l}\text { E13 } \\
2016(25)\end{array}$ & Pisetta Cecchini F & $\begin{array}{l}\text { Inseminación artificial y fecundación in vitro homólogas post } \\
\text { mortem: la filiación y la sucesión según la ley brasileña. Foro- - } \\
\text { Revista de Ciencias Jurídicas y Sociales Nueva Época. 2016;19(1): } \\
355-76 \text {. }\end{array}$ & Brasil & Espanhol \\
\hline $\begin{array}{l}\text { E14 } \\
2014(26)\end{array}$ & Alves LS, Oliveira CC & $\begin{array}{l}\text { Reprodução medicamente assistida: questões bioéticas. Revista } \\
\text { Bioética. 2014;22(1):66-75. }\end{array}$ & Portugal & Português \\
\hline $\begin{array}{l}\text { E15 } \\
2018(27)\end{array}$ & $\begin{array}{l}\text { Sánchez Ruiz } \\
\text { P, Martinez N, } \\
\text { Fernandez E }\end{array}$ & $\begin{array}{l}\text { Fecundación in vitro postmortem. Cultura de los cuidados. } \\
\text { 2018;50:171-9. }\end{array}$ & Espanha & Espanhol \\
\hline
\end{tabular}




\begin{tabular}{|c|c|c|c|c|}
\hline $\begin{array}{l}\text { E16 } \\
2015(28)\end{array}$ & Barbosa S et al. & $\begin{array}{l}\text { Extracción de semen post mortem: aspectos éticos y legales. } \\
\text { Descripción de caso y estudio en Colombia. Revista Colombiana } \\
\text { de Bioética. 2015;10(1):170-81. }\end{array}$ & Colômbia & Espanhol \\
\hline $\begin{array}{l}\text { E17 } \\
2015(29)\end{array}$ & Moadie OV & $\begin{array}{l}\text { Reflexión crítica sobre la fecundación post-mortem como TRA en } \\
\text { el ordenamiento jurídico colombiano y su incidencia en el ámbito } \\
\text { filial y sucesoral. Acta Académica. 2015;1:1-18. }\end{array}$ & Colômbia & Espanhol \\
\hline $\begin{array}{l}\text { E18 } \\
2014(30)\end{array}$ & Gomez Recuero Y & $\begin{array}{l}\text { Ley de Reproducción Humana Asistida y Capacidad para adquirir } \\
\text { en materia sucesoria. La justicia uruguaya: revista jurídica. 2014; } \\
\text { 150:1-10. }\end{array}$ & Uruguai & Espanhol \\
\hline $\begin{array}{l}\text { E19 } \\
2014(31)\end{array}$ & Morante VR & $\begin{array}{l}\text { ¿Debería permitir la futura ley peruana sobre técnicas de } \\
\text { reproducción humana asistida (TERAS) la figura del “embarazo } \\
\text { post mortem"?. Vox Juris. 2014;28(2):161-87. }\end{array}$ & Peru & Espanhol \\
\hline $\begin{array}{l}\mathrm{E} 20 \\
2018(32)\end{array}$ & Ramón FF & $\begin{array}{l}\text { Reflexiones acerca del documento indubitado en la fecundación } \\
\text { "post mortem". Actualidad Jurídica Iberoamericana. 2018;9:454-71. }\end{array}$ & Espanha & Espanhol \\
\hline $\begin{array}{l}E 21 \\
2017(33)\end{array}$ & Senna BC & $\begin{array}{l}0 \text { estabelecimento da filiação na lei de procriação medicamente } \\
\text { assistida portuguesa. Revista Eletrônica de Direito da Faculdade } \\
\text { Estácio do Pará. 2017;4(5):70-95. }\end{array}$ & Portugal & Português \\
\hline
\end{tabular}

Fonte: elaboração própria, 2020.

1 país ibero-americano abordado no estudo.

Cód.: código do estudo.

O Quadro 2 exibe a relação de documentos oficiais que complementam a revisão integrativa.

Quadro 2. Complementação legal oficial sobre TRHA post mortem a partir de uma amostra ibero-americana: Argentina, Brasil, Colômbia, Espanha, Peru, Portugal e Uruguai

\section{Documentos oficiais complementares}

Argentina. Proyecto de Código Civil y Comercial de la Nación. Infojus; 2012 (34).

Argentina

Argentina. Ley 26.994/2014. Código Civil y Comercial de 07/10/14. Infoleg; 2014 (35).

Argentina. Proyecto de ley: Técnicas de Reproducción Humana Asistida — Expediente 4058-D-2014 de 27/05/2014. Cámara de Diputados; 2014 (36).

Brasil. Resolução do Conselho Federal de Medicina (CFM) 2.168/2017. Conselho Federal de Medicina. Diário Oficial da

Brasil União de 10 de novembro de 2017; seção I, 73 (37).

Brasil. Lei 10.406/2002. Código Civil de 10/01/2002. Diário Oficial da União de 11 de janeiro de 2002; seção I (38).

Colombia. Proyecto de Ley 151/2001. Modificación del Código Civil y Penal referente a la aplicación de los métodos

Colômbia

de procreación humana asistida. Gaceta del Congreso. 2001; nº 558 (39).

Colombia. Ley 57/1887. Código Civil Colombiano. Congreso de la República de Colombia; 1887 (40).

España. Ley 14/2006. Sobre técnicas de reprodução humana assistida de 26/05/2006. Boletín Oficial del Estado de

Espanha

27 de mayo de 2006; $n^{0} 126$ (41).

España. Constitución española de 31/10/1978. Boletín Oficial del Estado de 29 de diciembre de 1978; n 311 (42). 


\begin{tabular}{|c|c|}
\hline Peru & $\begin{array}{l}\text { Perú. Anteproyecto de Reforma del Código Civil Peruano. Grupo de Trabajo Revisión y Mejoras Código Civil Peruano } \\
\text { de 1984. La Ley; } 2019 \text { (43). } \\
\text { Perú. Decreto Legislativo 295. Código Civil del Perú de 24/06/1984. Congreso de la República; } 1984 \text { (44). }\end{array}$ \\
\hline Portugal & 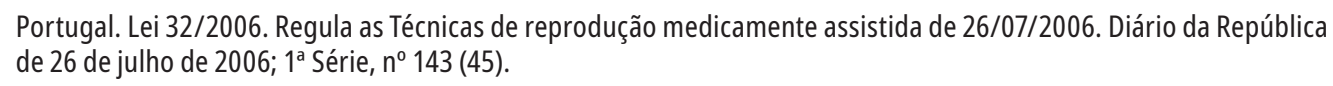 \\
\hline \multirow[t]{2}{*}{ Uruguai } & $\begin{array}{l}\text { Uruguay. Ley } 19.167 \text { sobre Técnicas de Reproducción Humana Asistida de 22/11/2013. Diario Oficial de } 29 \text { de } \\
\text { noviembre de 2013; } n^{\circ} 28854 \text { (46). }\end{array}$ \\
\hline & Uruguay. Ley 16.603 Código Civil de 19/10/1994. Diario Oficial de 21 de noviembre de 1994; n² 24177 (47). \\
\hline
\end{tabular}

Fonte: elaboração própria, 2020.

Os estudos recuperados abordam a situação ética e jurídica das TRHA post mortem dos seguintes países ibero-americanos: Argentina, Brasil, Colômbia, Espanha, Peru, Portugal e Uruguai (Figura 1). Os países da amostra $(n=7)$ constituem $32 \%$ do total dos países da Ibero-América $(\mathrm{n}=22)$. Apenas $14 \%(n=3)$ dos estudos abordam a conjuntura de mais de um país; o restante $86 \%(\mathrm{n}=18)$ concentra sua análise em um único país.

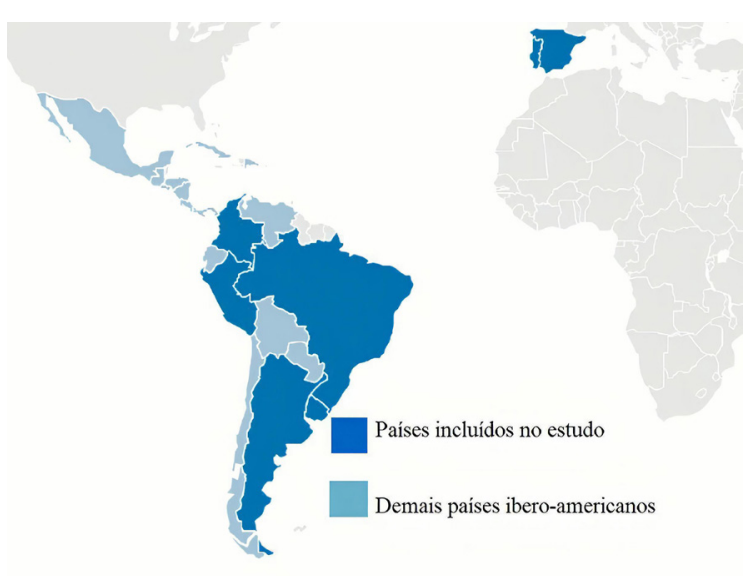

Figura 2. Distribuição geográfica dos países ibero-americanos incluídos no estudo

Fonte: elaboração própria, 2020.

Quanto ao período de publicação, 24\% (n = 5) dos estudos foram publicados em 2017; 19\% ( $\mathrm{n}=4) \mathrm{em}$ 2015; 19\% ( $n=4)$ em 2014; 14\% ( $=3)$ em 2018; 9\% $(n=2)$ em 2019; 5\% ( $n=1)$ em 2012; 5\% ( $n=1)$ em 2013 e 5\% (n=1) em 2016. Com relação ao idioma, $67 \%(n=14)$ dos estudos foram publicados em espanhol; $28 \%(n=6)$, em português e $5 \%(n=1)$, em inglês. Quanto ao tipo de estudo, 62\% $(\mathrm{n}=13)$ têm uma abordagem predominantemente jurídica, $29 \%(\mathrm{n}=6)$, uma abordagem ético-jurídica e $9 \%$ $(\mathrm{n}=2)$, eminentemente ética.

\section{Conteúdo da produção}

\section{Argentina}

$\mathrm{Na}$ Argentina, não existe norma que autorize especificamente ou regulamente as TRHA post mortem. O último anteprojeto do Código Civil e Comercial da Nação (CCCN) contemplava a filiação post mortem sob o artigo 563 - Filiação post mortem nas técnicas de reprodução assistida (34), mas a figura foi suprimida no marco do debate parlamentar (E6). O texto pretendia sanear, principalmente, duas questões: "o consentimento dado em vida para TRHA tem vigência para realizar a prática após a morte? É necessário que o consentimento fale concretamente que seu material genético seja utilizado após sua morte?" (E12, p. 208). No entanto, a norma deixava de fora questões referentes à filiação e às outras modalidades de reprodução póstuma, o que poderia ter significado maiores conflitos.

Frentes acadêmicas apresentaram consistentes argumentos contrários à inclusão das TRHA post mortem no texto final, por exemplo, o conflito ético-jurídico da fecundação post mortem, as discrepâncias filiatórias, o bem-estar do menor, a dignidade da pessoa, entre outros. Os doutrinários que se opõem à técnica advogavam pela proibição expressa, o que acabou não acontecendo. Já os 
favoráveis consideram que se perdeu a oportunidade de legislar sobre o assunto, porém concordam que sua exclusão foi correta devido às restrições da proposta (E3).

A filiação post mortem se mantém, no mínimo, nebulosa, mas a questão sucessória, paradoxalmente, estaria regulamentada (E3). Por um lado, "o novo CCCN regulamenta o sistema de filiação aplicável às TRHA, que se estrutura sobre a vontade procriacional" (E6, p. 151). Por outro, o artigo 2.279 do CCCN, referido à transmissão de direitos por causa de morte, expressa que: "Podem suceder ao causante: [...] c) as nascidas após de sua morte mediante técnicas de reprodução humana assistida, com os requisitos previstos no artigo 561" (35). Destarte, “o CCCN prevê, de maneira restritiva, a capacidade de herdar da pessoa que nascer como consequência de uma fecundação post mortem" (E3, p. 191).

O legislador entendeu que o consentimento expresso é a melhor forma de legitimar a autonomia no caso de reprodução assistida (E6). Por exemplo, sobre a ESP, à luz do ordenamento legal vigente, não seria possível outorgar um pedido de autorização judicial de conformidade com a regra que rege em matéria de atos de disposição do próprio corpo (art. 56 do $\mathrm{CCCN}$ ); ou seja, terceiros não podem decidir sobre um ato que depende unicamente da vontade da própria pessoa (E3).

Apesar da falta de normatização específica e sob o entendimento que o silêncio no CCCN não implicaria proibição (E12), "várias sentenças judiciais têm autorizado a aplicação post mortem das TRHA em casos de ausência consentimento ad hoc" (E6, p. 152), apelando frequentemente ao consentimento presumido (E3, E6). Salvo exceções, "a maioria tem reconhecido a virtualidade do consentimento nos casos de gametas e embriões crioconservados" (Е6, p. 153). Vontade procriacional reconstruída, consentimento por representação ou consentimento presumido (E3, E6, E12), são as propostas que confrontam os questionamentos sobre o caráter personalíssimo das decisões reprodutivas.

$\mathrm{O}$ caso de pedidos de transferência post mortem de embriões parece pacificado, haja vista a convergência doutrinária que infere a necessidade de procurar a implantação dos embriões crioconservados (E12).
O Projeto de Lei 4058-D-2014, que tramita no Congresso, no seu artigo 30, estipula a fecundação post mortem, incluindo a possibilidade de que o cônjuge possa decidir o destino do material genético do falecido (36). O projeto recebeu meia sanção, mas continua estancado. A Argentina é um dos países da região onde o debate acadêmico, social e religioso sobre as TRHA tem mantido constância e intensidade.

\section{Brasil}

"O legislador brasileiro não se preocupou em regulamentar exaustivamente a reprodução assistida” (E2, p. 37). Em razão das omissões legislativas, o CFM emitiu resoluções de caráter ético-normativo na tentativa de preencher ditas lacunas. Vide as sucessivas resoluções: CFM 1.358/1992; CFM 1.957/2010; CFM 2.013/13; CFM 2.121/2015 e CFM 2.168/2017 (E4, E5, E11). Esta última versão quanto à reprodução post mortem - mantém a redação de 2015.

No Brasil, não existe lei específica que autorize ou proíba as TRHA post mortem; sem embargo, estariam parcialmente regulamentadas com base em dois corpos normativos: o artigo 1.597 do Código Civil (CC) e a citada Resolução 2.168/2017 do CFM. Entretanto, persiste a controvérsia sobre o teor, a abrangência e a legitimidade na autorização das THRA post mortem (E2, E4, E5).

A Resolução CFM 2.168/2017, no seu inciso VIII - Reprodução assistida post mortem -, estabelece:

É permitida a reprodução assistida post mortem, desde que haja autorização prévia específica do(a) falecido(a) para o uso do material biológico criopreservado, de acordo com a legislação vigente (37).

Apesar de ser o único instrumento que aborda o tema de forma direta, determinando a permissibilidade para a realização das técnicas (E11), continuam os questionamentos sobre a competência normativa das resoluções do CFM. Alegam-se a falta de imperatividade erga omnes de ditas diretrizes (E2), a impossibilidade de a resolução inovar originariamente a ordem jurídica (E5) ou simplesmente a não designação a elas do valor de lei (E4).

O silêncio legislativo provoca uma série de dúvidas desde a esfera civil. O assunto é abordado pelo artigo 1.597 do CC: 
Presumem-se concebidos na constância do casamento os filhos: $[\ldots]$

II — havidos por fecundação artificial homóloga, mesmo que falecido o marido;

IV - havidos, a qualquer tempo, quando se tratar de embriões excedentários, decorrentes de concepção artificial homóloga (38).

O artigo em tela permite duas leituras possíveis: 1) a liberação das técnicas; 2) as repercussões filiatórias. Por um lado, uma boa parte dos doutrinários consideram que a previsão no cc vá em caminho a ser entendida como uma permissão legislativa (E2, E5, E13). As situações citadas pela norma civil (incisos III e IV) caracterizam a maior parte dos casos que envolvem TRHA post mortem (E5). Admitem-se como filhos aqueles havidos por fecundação artificial, mesmo que o marido titular do material genético (sêmen) tenha falecido; também se admitem como filhos aqueles havidos por fertilização in vitro, cujos embriões ficaram congelados até o momento da transferência ao útero, de acordo com a vontade dos pais (E2, E5, E13).

Confere a presunção de paternidade se a fecundação artificial ocorre após o prazo (300 dias) (inciso II, do art. 1.597). Mas, necessariamente, o de cujus deverá ter deixado seu consentimento prévio e expresso (E13), caso contrário, não será atribuída a filiação. A norma não contempla a possibilidade de realizar as técnicas em ausência de consentimento do de cujus. O ordenamento jurídico brasileiro prevê situações em que a manifestação de vontade produz efeitos mesmo após a morte do seu emitente (E2). Essa exigência é também prevista pelo Enunciado 106 do Conselho de Justiça Federal. Inclusive, o Provimento 52 da Corregedoria Nacional de Justiça, reforça a qualidade filiatória póstuma, pois prevê o direito de registro da criança concebida por reprodução assistida post mortem (E2). Em síntese, mesmo com as dificuldades interpretativas, para a maior parte dos doutrinários, a filiação estaria reconhecida ( $\mathrm{E} 4)$; diferentemente, o direito sucessório apresenta maiores obstáculos.

O artigo 1.798 do cc dispõe: "Legitimam-se a suceder as pessoas nascidas ou já concebidas no momento da abertura da sucessão" (38). "Os problemas iniciam-se quando os gametas do $\mathrm{de} \mathrm{cu}$ jus ou os embriões gerados com seu material genético estiverem congelados no momento da morte" (E13, p. 371). Sobre os embriões gerados pela fertilização in vitro, a discussão pousa no momento da concepção; já sobre os gametas se problematiza sua qualidade nondum conceptus - não concebido ao momento do falecimento do de cujus (E13). Em consequência, filhos nascidos via reprodução post mortem não teriam o direito sucessório garantido (E4). As dissonâncias são graves e evidentes, pois, na prática, poder-se-ia admitir filhos póstumos, mas sem direitos de herança, o qual é contrário ao princípio constitucional de igualdade entre filhos (E2, E13). No caso, a alternativa seria a disposição testamentária (art. 1.799 do CC) (E13).

Entre as principais controversas éticas descritas nos estudos e debatidas no Brasil, estão a orfandade da prole, o consentimento do doador falecido, as motivações egoísticas para o uso da técnica, o tratamento sucessório desigual conferido aos filhos póstumos, a dignidade da pessoa, entre outras (E2, E4, E13). Um aspecto que vem sendo considerado é a "reconstrução judicial da vontade" (E5). Não existindo autorização prévia e expressa do de cujus, e diante do pedido da viúva para o uso do material genético, os juízes têm considerado os antecedentes em função da "vontade procriacional" para deferir as autorizações (E2). O dispositivo é controvertido, pois constituiria uma forma disfarçada de consentimento presumido.

Vários projetos de lei já foram apresentados na tentativa de normatizar a reprodução assistida, incluída a post mortem (Е4). Atualmente, tem cinco projetos em processo de tramitação na Câmara de Deputados (Projeto de Lei 1.135/2003, Projeto de Lei $1.184 / 2003$, Projeto de Lei $2.061 / 2003$, Projeto de Lei 4.892/2012, Projeto de Lei115/2015).

\section{Colômbia}

No momento, a Colômbia não tem lei específica para TRHA post mortem, mas já houve uma séria intenção de legislar sobre o assunto no Título IX do Projeto de Lei 151/2001 (39). O regime proposto para a "procriação póstuma” (art. 40) era de caráter proibitivo, com a "finalidade de garantir o direito das crianças a ter uma família" (E17, 
p. 10). A contravenção da lei contemplava sanção penal e patrimonial - medida controversa e acertadamente rejeitada. Nesse sentido, "nada foi dito ainda, nem por via da tutela nem por via regulamentar" (E16, p. 179).

Ao não existir legislação que proíba tais procedimentos - inseminação, fecundação ou transferência embrionária - (E17), "a criança que nasce após 300 dias da morte do de cujus, biologicamente é seu filho, mas juridicamente não estaria dentro da presunção de paternidade, de acordo aos artigos 92 e 220 do Código Civil colombiano" (E8, p. 140). Nesse ponto, as soluções jurídicas são contraditórias, por exemplo, uma sentença do Tribunal Superior do Distrito Judicial de Bogotá - Sala de Família, em 2 de agosto de 1994, proferiu a presunção de paternidade (extramatrimonial) de uma criança gerada por inseminação post mortem, mesmo em ausência de autorização específica do falecido pai, com base na igualdade de direitos entre filhos (inc. 6, do art. 42 da Constituição Política da Colômbia) (E8). De maneira oposta, existem casos de solicitações de TRHA post mortem indeferidas por carência de legislação compatível (E17). Ainda, têm-se reportado casos de solicitação de ESP indeferidos pelos Comitês de Ética Hospitalar (E16).

Discute-se bastante o papel do consentimento informado, autonomia da vontade e sua representação documental (escritura pública, documento médico privado) (E8, E17). Também se colocam em tela as implicações éticas sobre o defunto e até que ponto a ESP pode ser considerada violatória da dignidade. Reconhece-se que o tema ainda "não foi aprofundado o suficiente e que a técnica pode desencadear situações sociais e psicológicas adversas e lesivas para a criança" (E16, p. 176).

Uma proposta de solução ética para o impasse da ESP, útil nas outras formas de TRHA post mortem, visa ao esclarecimento conjunto entre a solicitante (viúva/companheira) e a família (pais) do defunto. O protocolo modificado de Batzer foi proposto como um anteparo ético para a validação da ESP (E16). Também se discute que a importância da saúde mental ao momento da solicitação de TRH A post mortem, já que a requerente se encontra em período de luto, o que pode levar a adotar decisões impulsivas. Nesse ínterim, elementos como egoísmo ou narcisismo na decisão de gerar um filho póstumo devem ser correta e oportunamente avaliados (E16).

\section{Espanha}

A normatização da reprodução post mortem deriva-se do entendimento constitucional de que "tem que prevalecer o direito de procriar da viúva ou companheira do falecido" (E7, p. 299). Na Espanha, o tema está regulamentado no artigo $9^{\circ} \mathrm{da}$ Lei 14/2006, sob o enunciado: "Premoriência do marido" (41). "De uma forma sintética cabe afirmar que a regra geral é a proibição de tal hipótese, já que o parágrafo primeiro somente admite o uso das TRHA em vida dos cônjuges" (E7, p. 294). Porém, nos parágrafos $2^{\circ}$ e $3^{\circ}$, aplicam-se exceções que facultam a utilização do material genético do falecido quando cumpridos dois requisitos: existência de consentimento para a reprodução post mortem e que a técnica seja realizada até um ano após o falecimento (E1, E7, E8, E15). Contudo, a exceção tem tal amplitude que, na prática, ganha rango de lei, com o mesmo conteúdo e efeitos que a aludida regra geral (E7). É por isso que o rigor é de uma autorização explícita.

A manifestação do de cujus só é válida se lavrada em documento de autorização de técnicas de reprodução, escritura pública, testamento, escrito de instruções prévias (E1), respeitando os requisitos de expressão livre, consciente e formal. Todos esses documentos têm em comum o assentimento para a prática (E20). Tal manifestação não pode ser substituída por declaração de familiares nem por ordem judicial (E1). Sem embargo, existe uma exceção, segundo o artigo 9.2, Lei 14/2006: "se presume outorgado o consentimento do homem quando a mulher já houvesse iniciado o processo de reprodução assistida para a transferência de embriões constituídos antes da morte do mencionado homem" (41). Nessa instância, o debate se concentra em determinar qual é, propriamente, o início desse processo.

Fica claro que, apesar das exceções, a legislação espanhola foi muito zelosa ao tentar proteger o caráter exclusivo e íntimo da manifestação da vontade (E20).

Sobre a filiação, "se o homem autoriza em vida e a TRHA se realiza dentro dos 12 meses após a morte, se reconhecerá a paternidade, 
independentemente se os progenitores estivessem ou não casados" (E1, p. 125). Para tentar se harmonizar com o disposto no cC, com relação ao tipo de filiação, a norma a considera uma filiação de tipo matrimonial (E7). Já no suposto de realizar uma procriação post mortem "ilegal" (por ausência de consentimento do homem ou por ter expirado o prazo de 12 meses), à descendência não lhe seria reconhecida a paternidade do homem falecido (art. 9.1, Lei 14/2006) (E1). A possibilidade de ter filhos póstumos juridicamente não reconhecidos entra em contradição com o parágrafo $3^{\circ}$ do artigo $39 \mathrm{da}$ Constituição Espanhola (E1, E7, E15, E20), que cita: "os pais devem prestar assistência de toda ordem aos filhos havidos dentro e fora do matrimônio" (42). O citado artigo $9^{\circ}$ "não atribui de modo explícito direitos sucessórios aos nascidos fruto destas técnicas, mas pode-se inferir a atribuição implícita de tais direitos ao determinar ou facilitar a determinação da filiação da criança em relação ao homem falecido" (E7, p. 315).

A lei não se pronunciou sobre o destino específico dos embriões excedentários gerados por TRHA post mortem (depois de transcorridos 12 meses), sendo aplicada a norma geral de destino de embriões (doação, investigação, destruição) (E1). Por outro lado, "o artigo 9 somente regulamenta a reprodução artificial post mortem no casal heterossexual. A literalidade do preceito, entre outras razões, impede que se estenda tal hipótese a um matrimônio ou casal de fato homossexual, de homens ou mulheres" (E7).

Alguns assuntos discutidos e objetados na reprodução post mortem são: procriação responsável, desvio da finalidade terapêutica das técnicas de reprodução, direitos da criança com relação aos seus pais, percepção do embrião como realidade pessoal, entre outros (E1, E15). Sobre a ESP, fica em discussão a validez do eventual consentimento para o procedimento, já que a norma não é muito clara nesse aspecto. Por fim, o aperfeiçoamento da constatação da vontade, por meio de um "documento indubitado", é proposto e discutido no âmbito do novo cenário digital (E20).

\section{Peru}

O Peru não tem legislação específica sobre a reprodução post mortem; sem embargo, é necessário destacar que se encontra em fase avançada de tramitação a Proposta de Reforma do Código Civil de 1984 (43), na qual se introduz de forma inédita a questão da reprodução medicamente assistida post mortem.

As novas TRHA possibilitaram a concepção de um filho quando seu progenitor não se encontra mais vivo. Na norma civil peruana (44), os filhos póstumos, aqueles concebidos pelo pai em vida e nascidos após seu falecimento, mas antes dos 300 dias da dissolução do matrimônio (E19), teriam reconhecida a filiação. Quando o concebido nasce após 300 dias da morte do pai, não pode ser considerado filho do de cujus, mesmo que biologicamente o seja (E19). A estes últimos uma parte da doutrina os denomina "filhos superpóstumos" (E9).

$\mathrm{Na}$ doutrina peruana, propõem-se algumas soluções pragmáticas para a reprodução post mortem (E9, p. 135):

1) se o filho nasce dentro do prazo, aplica-se a presunção de paternidade, portanto é matrimonial e do defunto;

2) e o filho nasce fora do prazo, deve-se diferenciar, se é inseminação ou transferência embrionária;

3) se a fecundação é heteróloga (com sêmen de doador), somente a vontade expressa do $\mathrm{de} \mathrm{cu}$ jus proferiria a filiação, inclusive matrimonial.

Se olharmos o projeto de reforma, com relação à determinação da filiação post mortem (art. 415-A), este estipula:

Nos casos de Reprodução Medicamente Assistida Post Mortem com material genético do marido, o filho será matrimonial sempre que exista assentimento expresso e se realize dentro do prazo máximo de seis meses desde a morte do marido. A mesma regulamentação se aplica aos embriões crioconservados (43).

Embora a regulamentação proposta tente resolver os conflitos filiatórios e suas implicâncias hereditárias, no atual contexto, é inevitável que uma inseminação post mortem não finalize em reclamação judicial. Como se pode observar, o texto aplica de maneira expressa e direta a condição filiatória matrimonial, supeditada a um consentimento válido - devendo concordar com a presunção de 
paternidade disposta no artigo 361 do CC (E19). O prazo de seis meses é um período fixado com o fim de o filho nascer protegido pela presunção "pater est" e evitar a pendência da partilha hereditária (E19). A transferência embrionária post mortem estaria contemplada sob os mesmos termos. Percebe-se a permissibilidade da proposta ao introduzir de maneira expressa a figura da reprodução medicamente assistida post mortem, o que, obviamente, significaria a definitiva autorização legal para a prática.

Desde a perspectiva bioética, parte da doutrina considera que as TRHA post mortem são violatórias do melhor interesse da criança, haja vista a orfandade "ab inittio" e a privação do filho de se desenvolver num ambiente biparental (E19). É criticada a realização das técnicas em ausência de problemas de fertilidade, já que contraria o disposto na Lei Geral de Saúde. Destaca-se a importância da verificação do consentimento prévio e expresso; sem embargo, alguns doutrinários admitem que pode ser razoavelmente inferido (E9). Por fim, a carência de legislação produz que, pela grande oferta de serviços reprodutivos, a práxis esteja sujeita ao critério ético de médicos e biólogos (E19).

\section{Portugal}

A reprodução post mortem é regulada pelo artigo 22 da Lei 32/2006. A epígrafe da norma intitula-se "inseminação post mortem"; mas, estritamente falando, deveria ser chamado "transferência de embriões post mortem", dado que apenas esta última é permitida (E10). Assim:

Artigo 22. Inseminação Post mortem

1 - Após a morte do marido ou do homem com quem vivia em união de fato, não é lícito à mulher ser inseminada com sêmen do falecido, ainda que este haja consentido no ato de inseminação.

2 - O sêmen que, com fundado receio de futura esterilidade, seja recolhido para fins de inseminação do cônjuge ou da mulher com quem o homem viva em união de fato é destruído se aquele vier a falecer durante o período estabelecido para a conservação do sêmen.

3 - É, porém, lícita a transferência post mortem de embrião para permitir a realização de um projeto parental claramente estabelecido por escrito antes do falecimento do pai, decorrido que seja o prazo considerado ajustado à adequada ponderação da decisão (45).

Os dois primeiros incisos se ocupam das duas modalidades mais frequentes. O inciso 1 proíbe de maneira patente a inseminação post mortem; já o inciso 2 impossibilita a fertilização post mortem. "Os legisladores portugueses definiram o regime jurídico na época da fecundação: caso esta ocorra antes da morte do pai permite-se que os embriões sejam transferidos, mas se ainda não tiver ocorrido nessa data, não será mais possível apesar das evidências relacionadas aos desejos do falecido" (E10, p. 192). Ou seja, somente é considerada a transferência de embrião assumido como projeto parental antes da morte do pai (E14). A autorização do de cujus deve ser em documento público, e o embrião deve ser utilizado pela viúva ou pela companheira nos três meses seguintes à data da morte (E21).

Vale a pena assinalar que a redação da lei dispõe unicamente a possibilidade de solicitação por parte da mulher supérstite e não do eventual homem supérstite; ou seja, "todo o regime da lei parte do pressuposto que aquele que morre é o elemento masculino" (E10, p. 192).

Os artigos 23 e 26 complementam os aspectos referidos às TRH A post mortem. Por exemplo, o artigo 23 da referida lei regulamenta a paternidade decorrente da eventual violação da proibição da técnica. Desse modo:

Artigo 23. Paternidade.

1 - Se da violação da proibição a que se refere o artigo anterior resultar gravidez da mulher inseminada, a criança que vier a nascer é havida como filha do falecido.

2 - Cessa o disposto no número anterior se, à data da inseminação, a mulher tiver contraído casamento ou viver há pelo menos dois anos em união de fato com homem que, nos termos do artigo $14 .^{\circ}$, dê o seu consentimento a tal ato, caso em que se aplica o disposto no n. 3 do artigo $1839 .^{\circ}$ do Código Civil (45).

A paternidade estaria garantida mesmo na ocasião da violação do preceito geral; entretanto, a cláusula no inciso 2 delimita tal concessão. Pela lei de PMA, estabelece-se que a filiação, mesmo na hipótese de inseminação/fertilização post mortem, se dará em relação ao falecido, contornando com isso a proibição legal (E10). Após o período de 300 
dias previstos na lei, em que se aplica a presunção de paternidade, em tese, não poderá ser considerado filho do falecido (art. 1.829 do CC) (E21). Não se estabelecem de forma clara as condições para a vocação sucessória.

A normatização da reprodução post mortem coloca a tônica no estatuto ético, jurídico e ontológico da vida humana (E10, E14). O direito a uma família biparental é a justificativa para a não admissão da reprodução post mortem, desestimulando "a criação voluntária de uma família unilinear póstuma" (E21, p. 90). Por outro lado, a normativa visa à proteção post mortem dos embriões crioconservados, "como forma de proteger o patrimônio genético desse ser já formado desde o momento da concepção” (E21, p. 90), “já que a morte não os deve converter em lixo desrespeitosamente manipulável ou comercializável” (E14, p. 74).

Para a lei portuguesa a reprodução medicamente assistida só deve ser considerada mediante o diagnóstico de infertilidade ou perante doença grave de transmissão genética, em casais heterossexuais, com relação estável há pelo menos dois anos, maiores de 18 anos e sem patologia psíquica associada (E14, p. 72).

Isso leva a discutir o acesso às técnicas de RMA para casais homossexuais, pois a norma não particulariza nem estimula tal possibilidade.

Atualmente no país existem algumas iniciativas legislativas - de caráter permissivoque pretendem regulamentar as TRHA post mortem. Devido ao estágio avançado de tramitação, o panorama normativo em Portugal pode mudar substancialmente.

\section{Uruguai}

O artigo $9^{\circ}$ da Lei 19.167 define as condições para a TRHA post mortem e as denomina "situação especial":

Poderá realizar-se fertilização de gametas ou transferir embriões originados numa pessoa que houvesse falecido, sempre que esta houvesse outorgado previamente por escrito seu consentimento para aquilo e dentro dos 365 dias após seu falecimento (46).

O artigo em tela libera ou autoriza a realização das TRHA post mortem, mas condiciona a necessidade de consentimento escrito e dentro do prazo de um ano (E11, E18). Pelo teor da redação, a lei não se restringe somente à morte do varão. Inclusive, na hipótese da morte da mulher, elencam-se alguns cruzamentos com outras figuras jurídicas (E18); não obstante, cabe lembrar que a lei uruguaia proíbe a gestação por substituição, salvo uma exceção (art. 25) (E18). Desde o início, a lei foi vista como um "grande avanço", pois permitia o acesso à universalização das técnicas reprodutivas (E11).

O consentimento para a fecundação ou implantação post mortem é o elemento principal para determinar a relação filiatória da criança nascida através da técnica. Sem a existência de documento escrito, a criança não terá vínculo jurídico com o pai genético (E18). O prazo de 365 dias, como na maioria das legislações, visa ao enquadramento da presunção de filiação matrimonial. Se uma criança nasce após os 300 dias como dispõe artigo 215 do CC, ainda estaria dentro dos 365 dias de cobertura pela Lei 19.167 e, assim, seu caráter filiatório seria extramatrimonial (E18). Em matéria sucessória, o artigo 835 do CC dispõe: "São incapazes: 1 - quem não estivesse concebido ao tempo de se abrir a sucessão" (47). O filho "não teria capacidade para adquirir na sucessão de seu pai, já que não estaria concebido ao momento do falecimento" (E18, p. 7). Isso significa que a sucessão seria incompatível com a inseminação post mortem, em que, ao momento da morte do de cujus, só existem gametas.

Sobre os desdobramentos da transferência embrionária, como em outros países, prossegue o eterno debate sobre o real estatuto jurídico do embrião e qual seria o momento da concepção (fertilização versus implantação). Como é lógico supor, as posições são diametralmente opostas e aparentemente inconciliáveis. Em várias passagens, a citada lei reforça - de forma positiva - o compromisso legislativo com a imprescindibilidade do consentimento informado, sua ação e ratificação. Sem embargo, não dispõe que o consentimento seja realizado ante instrumento público ou privado, deixando margem à insegurança jurídica (E18).

\section{Considerações finais}

A revisão integrativa da literatura identificou os principais parâmetros normativos das TRHA post mortem nos países ibero-americanos estudados (Quadro 3). 
Quadro 3. Principais parâmetros sobre a legislação das TRHA post mortem a partir de uma amostra ibero-americana: Argentina, Brasil, Colômbia, Espanha, Peru, Portugal e Uruguai

\begin{tabular}{c|c|c|c|c} 
& $\begin{array}{c}\text { Proibida pela } \\
\text { legislação vigente }\end{array}$ & $\begin{array}{c}\text { Permitida com consentimento } \\
\text { informado escrito }\end{array}$ & $\begin{array}{c}\text { Sem consentimento } \\
\text { informado escrito }\end{array}$ & $\begin{array}{c}\text { Leis ou normativas } \\
\text { específicas }\end{array}$ \\
\hline Argentina & - & - & - & - \\
\hline Brasil & - & $(n / e)$ & - & $(n / e)$ \\
\hline Colômbia & - & - & - & - \\
\hline Espanha & - & + & - & + \\
\hline Peru & - & - & - & - \\
\hline Portugal & + & $(e)$ & - & + \\
\hline Uruguai & - & + & +
\end{tabular}

Fonte: elaboração própria, 2020. Baseado no modelo de Dostal et al. (48) e Barbosa et al. (28).

Nota: $n / e$ : Norma ética. Resolução emitida pelo Conselho Federal de Medicina, exige consentimento informado para a reprodução post mortem.

e: Situação especial. É permitida a transferência post mortem de embriões; deve existir o consentimento prévio e escrito.
Também foi possível recuperar as principais normativas que versam sobre o assunto. Cabe salientar que, nesta análise, não foram consideradas as alternativas judiciais ou jurisprudenciais, pois independem de legislação específica (Quadro 4).

Quadro 4. Principais normativas sobre TRHA post mortem a partir de uma amostra ibero-americana: Argentina, Brasil, Colômbia, Espanha, Peru, Portugal e Uruguai

\begin{tabular}{llll} 
& Principal normativa & Tipo de documento & Principal posicionamento \\
\hline Argentina & Não existe & -- & Sem posicionamento \\
\hline Brasil & Res. CFM 2.168/2017 & $\begin{array}{l}\text { Resolução de Conselho } \\
\text { profissional (CFM) }\end{array}$ & Favorável ( $/ e)$ \\
\hline Colômbia & Não existe & -- & Sem posicionamento \\
\hline Espanha & art. $9^{\circ}$ da Lei 14/2006 & Lei Nacional & Favorável \\
\hline Peru & Não existe & -- & Sem posicionamento \\
\hline Portugal & art. 22 da Lei 32/2006 & Lei Nacional & Não favorável (e) \\
\hline Uruguai & art. $9^{\circ}$ da Lei 19.167/2013 & Lei Nacional & Favorável \\
\hline
\end{tabular}

Fonte: elaboração própria, 2020.

Nota: não foram consideradas as alternativas judiciais que independem de legislação específica.

n/e: Norma ética. Resolução emitida pelo Conselho Federal de Medicina, exige consentimento informado para a reprodução post mortem.

$e$ : Situação especial. Norma proibitiva das TRHA post mortem, porém é permitida a transferência post mortem de embriões; deve existir o consentimento prévio e escrito.
A análise comparativa da realidade ético-normativa expõe uma certa carência de regulamentação específica das TRHA post mortem nos países da amostra. Dos países estudados, apenas a Espanha e o Uruguai têm regulamentado alguns aspectos das THRA post mortem. A Espanha, por exemplo, autoriza o uso do material genético do homem falecido, sendo necessário o consentimento do de cujus, e 
que a técnica de reprodução seja realizada dentro dos 12 meses após o falecimento. Pela natureza e pelo teor da normativa, na prática, é considerada uma autorização/liberação expressa para a realização das técnicas. Já no Uruguai, a fecundação post mortem e a transferência póstuma de embriões originados com material do de cujus estão plenamente autorizados, devendo constar consentimento prévio e ser realizada no prazo de 365 dias após o falecimento.

Do outro lado, Portugal é o único país da amostra que tem proibição expressa, via lei, para a realização de reprodução post mortem. No entanto, tal proibição contém uma exceção. No país luso, é lícita a transferência post mortem de embriões condicionada à existência de consentimento escrito prévio ao falecimento do titular. A Argentina, a Colômbia e o Peru compartilham uma situação similar. Não existe lei específica nem normativa auxiliar que autorize ou proíba as TRHA post mortem. A Argentina tem precedentes judiciais que liberam determinados procedimentos reprodutivos póstumos. Na Colômbia, existem escassos relatos de solicitações judiciais para aplicação de TRHA post mortem; os casos relevantes têm tido desfechos divergentes. No Peru, a casuística ainda é exígua. $\mathrm{O}$ Brasil encontra-se numa situação especial e intermediária em relação aos outros países estudados. Não existe uma lei ou norma específica que autorize ou proíba a reprodução post mortem ou que regulamente suas variadas consequências. Contudo, alguns instrumentos legais têm sido interpretados como "adequados" para inferir uma liberação dos procedimentos no país: o teor permissivo da Resolução 2.168/2017 do CFM e a interpretação evolutiva do artigo 1.597 do CC. De fato, alguns precedentes jurisprudenciais que autorizaram a realização de TRHA post mortem foram fundamentados em interpretações extensivas das normas citadas e/ou alegando a proteção de princípios constitucionais.

Todos os países estudados têm, em maior ou menor medida, sérios problemas para adequar suas normas cíveis ante os eventuais casos de gerados por reprodução post mortem. O motivo é simples, as legislações não foram pensadas no contexto das técnicas de reprodução assistida além da vida. Embora a Espanha e o Uruguai conseguiram sanear parcialmente o problema filiatório, as consequências sucessórias no concebido póstumo ainda permanecem nebulosas.

Por sua vez, os principais questionamentos éticos nos países ibero-americanos versam fundamentalmente sobre a legitimidade do consentimento para a utilização póstuma do material genético, o tratamento desigual proferido à prole, o direito à biparentalidade, o estatuto jurídico do embrião, a proteção da dignidade humana, o filho como fim e não como meio, as motivações egoístas para a procriação póstuma, o respeito pela integridade corpórea do falecido, entre outros.

A comunidade médica, particularmente a médico-legal, deve adotar uma atitude ativa no debate bioético e biojurídico, especialmente, nas questões dilemáticas que envolvem a vida, a saúde e a dignidade das pessoas. A tarefa não é fácil. Os cruzamentos entre figuras jurídicas controvertidas como a gestação por substituição, as novas configurações familiares como os casais homoafetivos ou a instabilidade das demandas sociais convergem em problematizar, ainda mais, o atual panorama ético-normativo. Percebe-se que a tendência se inclina à regulamentação das técnicas, em consequência, algumas áreas de competência para médicos, assistentes ou peritos, potencialmente poderão ser exploradas. Por exemplo, na presença de imprecisões sobre a "verdade genética" do filho póstumo ou quando superados os prazos de presunção de paternidade estipulados por lei, os magistrados podem requerer a investigação da paternidade, ato restrito ao perito especializado. $\mathrm{O}$ estado emocional do cônjuge supérstite é um componente digno de ser abordado; alguns centros americanos sugerem um acompanhamento médico e psicológico de até um ano prévio à efetivação da inseminação ou fertilização post mortem (49). De fato, algumas evidências demonstraram que o aconselhamento oportuno e prolongado levou às viúvas a desistirem da utilização do material genético do falecido marido (50). A labilidade emocional após a morte do cônjuge pode induzir solicitações precipitadas ou desmedidas; desse modo, uma avaliação da aptidão mental para a requisição de reprodução 
póstuma pode ser solicitada no contexto do processo judicial. Por sua vez, médicos assistentes das áreas de emergências e unidades de cuidados intensivos já se deparam com solicitações de ESP " $a$ beira do leito"; esses profissionais devem ter competência teórica suficiente sobre as implicâncias éticas, legais e religiosas que circundam as solicitações de reprodução póstuma (51). Uma dessas competências tem a ver com capacidade de executar, interpretar, interpelar ou questionar os pormenores - forma e conteúdo- da documentação médico-legal nas mais variadas circunstâncias (na solicitação formal da viúva, na comunicação com os outros familiares, no consentimento prévio do de cujus, no encaminhamento ao comitê de ética hospitalar, nas requisições judiciais etc.). Algumas dessas atuações já estão padronizadas em países onde a técnica é permitida - por exemplo, Israel, Reino Unido, Estados Unidos (52). Já nos países com legislação permissiva que fazem parte de nossa amostra, nem Uruguai nem Espanha têm protocolos para orientar a atuação unificada do pessoal médico em face dos conflitos emergentes.

A procriação a partir do uso de material de genitor falecido tem crescido em casuística e relevância, ganhando o apoio de togados e doutrinários. Porém, ainda é palpável a rejeição social entre os leigos (53), principalmente em razão dos sérios conflitos morais, éticos e religiosos que tais técnicas produzem (50), além do constrangimento natural provocado pela simples menção da ideia. Essa desconfiança social parece repercutir de forma direta na ausência de normatização específica na região ibero-americana. Tal atitude seria o reflexo da complexidade da matéria, dos variados entraves jurídicos e, principalmente, da dissensão moral. O debate confronta posições dificilmente compatíveis entre si, já que, em determinados pontos, se devem definir aspectos críticos, tais como o estatuto jurídico do embrião, a titularidade do material genético ou a validade póstuma da vontade procriacional, entre outros. Diante desses conflitos ainda irresolutos, a postura protecionista resulta uma opção eticamente viável, quando focada na defesa da vida e da dignidade dos mais vulneráveis (embriões, crianças).
Em definitiva, a enorme quantidade de atritos e óbices pode nos levar a reflexionar: será que vale a pena investir todos esses esforços em uma técnica tão contracorrente? Será que já é tarde demais para retroagir até um espaço de diálogo e reconsideração dos pormenores éticos da reprodução além da vida?

\section{Conclusões}

Com algumas exceções, a maior parte dos países ibero-americanos da amostra não tem legislações específicas que regulamentem os variados aspectos das TRH A post mortem. Do conjunto estudado, unicamente Uruguai e Espanha têm normatização permissiva para a reprodução post mortem. O primeiro de forma expressa, e o último de forma implícita. Portugal tem normativa proibitiva para a maioria das técnicas de reprodução post mortem, excetuando a transferência póstuma de embriões. A Argentina, a Colômbia e o Peru estão desregulamentados para TRHA post mortem, tendo como alternativa de autorização a via judicial. O Brasil encontra-se numa situação especial. Por um lado, inexiste regulamentação específica; por outro, alguns consideram o caráter normativo-vinculante da Resolução 2.168/2017 do CFM, além da interpretação evolutiva do artigo 1.597 do CC.

O debate bioético gira em torno das tensões na relação quadrangular entre a dinâmica da autonomia humana, o estatuto do material genético (gametas e embriões), a proteção da prole e os direitos reprodutivos. A rejeição social das técnicas e a ausência de regulamentação na região parecem ser o reflexo da complexidade da matéria, dos sérios entraves jurídicos e, principalmente, da dissenção moral. Na presença dos variados conflitos emergentes, a postura protecionista da vida e da dignidade dos mais vulneráveis é uma alternativa eticamente viável.

Ante o advento dessas técnicas, o papel da medicina legal deve ser ativo, tanto no debate acadêmico como no labor pericial. Apesar da tendência, o debate não pode deixar de questionar de forma incisiva a legitimidade/ilegitimidade ética e jurídica da reprodução além da vida. 


\section{Referências}

1. Aziza-Shuster E. Ethics and society: A child at all costs: Posthumous reproduction and the meaning of parenthood. Hum Reprod [internet]. 1994;9(11):2182-5.http:// dx.doi.org/10.1093/oxfordjournals.humrep.a138414

2. Sabatello M. Posthumously conceived children: An international and human rights perspective. JL \& Health [internet]. 2014 [acesso em 20 de abril de 2020];27:2967. Disponível em: https://engagedscholarship.csuohio.edu/jlh/vol27/iss1/5

3. Shefi S, Raviv G, Eisenberg ML et al. Posthumous sperm retrieval: Analysis of time interval to harvest sperm. Hum Reprod [internet]. 2006;21(11):2890-3. http://dx.doi.org/10.1093/humrep/del232

4. Hurwitz JM, Batzer FR. A guest editorial: Posthumous sperm procurement: Demand and concerns. Obstet Gynecol Surv [internet]. 2004;59(12):806-8. http://dx.doi.org/10.1097/01.ogx.0000145929.69990.d6

5. Blyth E, Cameron C. The welfare of the child. An emerging issue in the regulation of assisted conception. Hum Reprod [internet]. 1998;13(9):2339-42. htpp://dx.doi.org/10.1093/humrep/13.9.2339

6. Tremellen K, Savulescu J. A discussion supporting presumed consent for posthumous sperm procurement and conceptionReprod Biomed Online [internet].2015;30(1):6-13. https://dx.doi.org/10.1016/j.rbmo.2014.10.001

7. Carbajal M. Autorizaron la extracción de semen de un hombre fallecido: Para que haya vida tras la muerte. Página 12 [internet]. 3 de novembro de 1999 [acesso em 20 de abril de 2020];21. Disponível em: https:/www.pagina12.com.ar/1999/99-11/99-11-03/pag21.htm

8. Rezzieri L. Direitos hereditários do concebido post mortem no ordenamento jurídico brasileiro: uma análise crítica a partir do sopesamento entre princípios sucessórios e constitucionais [monografia]. Florianópolis: Universidade Federal de Santa Catarina; 2015 [acesso em 20 de abril de 2020]. 142 p. Disponível em: https://repositorio.ufsc.br/xmlui/bitstream/handle/123456789/133838/TCC\%20para\%20reposit\%C3\%B3rio.pdf? sequence $=1 \&$ is Allowed $=y$

9. Nogueira RD. O regime jurídico da procriação medicamente assistida Post Mortem e as suas implicações no direito sucessório português [Dissertação de Mestrado]. Braga: Universidade do Minho; 2016 [acesso em 20 de abril de 2020]. 145 p. Disponível em: https://repositorium.sdum.uminho.pt/bitstream/ 1822/52019/1/Daniela\%20Alexandra\%20Ribeiro\%20 Nogueira.pdf
10. Orr RD, Siegler M. Is posthumous semen retrieval ethically permissible?. J Med Ethics [internet]. 2002;28(5):299302.http://dx.doi.org/10.1136/jme.28.5.299

11. Guzmán JA. Aspectos bioéticos y jurídicos del manejo del cadáver: un análisis de su estatus mortem y su consonancia ética en la praxis. Vida y Ética [internet]. 2018 [acesso em 20 de abril de 2020];19(2):77-141. Disponível: https://repositorio.uca.edu.ar/handle/123456789/8812

12. Ganong LH. Integrative reviews of nursing research. Res Nurs Health [internet]. 1987;10(1):1-11. http://dx.doi.org/10.1002/nur.4770100103

13. Enguer GP, Ramón FF. Dilemas bioéticos y jurídicos de la reproducción asistida en la sociedad actual en España. Rev. latinoam. bioét. [internet]. 2018;18(1):10435. http://dx.doi.org/10.18359/rlbi.3160

14. Ribeiro RB. Reprodução Assistida Post Mortem no Direito Brasileiro. Rev. Biodireito e D reito dos Animais [internet]. 2017;3(1):36-56 http://dx.doi.org/10.26668/ IndexLawJournals/2525-9695/2017.v3i1.2026

15. Herrera M. Un debate complejo: la técnica de reproducción humana asistida post mortem desde la perspectiva comparada. Rev. IUS [internet]. 2017;11(39):185-206. http://dx.doi.org/10.35487/rius.v11i39.2017.304

16. Leite TH. Análise crítica sobre a evolução das normas éticas para a utilização das técnicas de reprodução assistida no Brasil. Ciênc. Saúde Colet. [internet]. 2019; 24(3):917-28. http://dx.doi.org/10.1590/ 1413-81232018243.30522016

17. Oliveira NB, Sá MF. Panorama bioético e jurídico da reprodução humana assistida no Brasil. Rev. bioét. derecho [internet]. 2015; 34:64-80. http://dx.doi. org/10.1344/rbd2015.34.12067

18. Geri L. Consentimiento presunto a las técnicas de reproducción humana asistida post mortem. Criterios para su regulación en Argentina. Rev. bioét. derecho [Internet]. 2019;46:149-65. http://dx.doi.org/10.1344/rbd2019.0.22987

19. Rodríguez Guitián AM. La reproducción artificial post mortem en España: estudio ante un nuevo dilema jurídico. Rev. Bol. Der. [internet]. 2015 [acesso em 20 de abril de 2020];20:292-322. Disponível em: http://www.scielo.org.bo/pdf/rbd/n20/n20_a13.pdf

20. Bernal CJ. Reproducción asistida y filiación. Tres casos. Opin. jurid. [internet]. 2013 [acesso em 20 de abril de 2020];12(24):135-150. Disponível em: http://www.scielo.org.co/pdf/ojum/v12n24/v12n24a09.pdf 
21. Varsi Rospigliosi E. Determinación de la filiación en la procreación asistida. Rev. IUs [internet]. 2017;11(39): 109-37. htpp://dx.doi.org/10.35487/rius.v11i39.2017.300

22. Dantas E, Raposo V. Legal aspects of post-mortem reproduction: A comparative perspective of French, Brazilian and Portuguese legal systems. Med Law [internet]. 2012 [acesso em 20 de abril de 2020]; 31(2):181-98. Disponível em: https://heinonline.org/ HOL/LandingPage?handle=hein.journals/mlv31\&di$\mathrm{v}=17$ \&id $=$ \&page $=$

23. Abreu CS et al. Estudo das regulamentações de reprodução humana assistida no Brasil, Chile, Uruguai e na Argentina. Reprod Clim [internet]. 2014;29(1):27-31. http://dx.doi.org/10.1016/j.recli.2014.07.001

24. Krasnow AN. La filiación por técnicas de reproducción humana asistida en el Código Civil y Comercial argentino. Un avance que permite armonizar la norma con la realidad. Rev. Derecho Privado [internet]. 2017;32(1):175-217. http://dx.doi. org/10.18601/01234366.n32.07

25. Pisetta Cecchini F. Inseminación artificial y fecundación in vitro homólogas post mortem: la filiación y la sucesión según la ley brasileña. Foro [internet]. 2016;19(1):355-76. htpp://dx.doi.org/10.5209/FORO.53397

26. Alves LS, Oliveira CC. Reprodução medicamente assistida: questões bioéticas. Rev. bioét [internet]. 2014;22(1):66-75. htpp://dx.doi.org/10.1590/S198380422014000100008

27. Sánchez Ruiz P, Martinez N, Fernandez E. Fecundación in vitro postmortem. Cultura de los cuidados [internet]. 2018;50:171-9. http://dx.doi.org/10.14198/ cuid.2018.50.16

28. Barbosa $\mathrm{S}$ et al. Extracción de semen post mortem: aspectos éticos y legales. Descripción de caso y estudio en Colombia. Rev. colomb. bioét. [internet]. 2015;10(1):17081. htpp://dx.doi.org/10.18270/rcb.v10i1.690

29. Moadie OV. Reflexión crítica sobre la fecundación post-mortem como TRA en el ordenamiento jurídico colombiano y su incidencia en el ámbito filial y sucesoral. Acta académica [internet]. 2015 [acesso em 20 de abril de 2020];1:1-18. Disponível em: http://cdsa.aacademica.org/000-061/327.pdf

30. Gomez Recuero Y. Ley de Reproducción Humana Asistida y Capacidad para adquirir en materia sucesoria. La justicia uruguaya: revista jurídica [internet]. 2014 [acesso em 20 de abril de 2020];150:1-10. Disponível em: https://www.apuruguay.org/sites/default/files/ Yanel-trabajo-TRHA.pdf
31. Morante VR. ¿Debería permitir la futura ley peruana sobre técnicas de reproducción humana asistida (Teras) la figura del Embarazo Post Mortem?. Vox Juris [internet]. 2014 [acesso em 20 de abril de 2020];28(2):161-87. Disponível em: https://www.aulavirtualusmp.pe/ojs/index.php/VJ/ article/view/14/15

32. Ramón FF. Reflexiones acerca del documento indubitado en la fecundación post mortem. Actual. juríd. iberoam. [internet]. 2018 [acesso em 20 de abril de 2020];9:454-71. Disponível em: http://www.revista-aji. com/articulos/2018/9/454-471.pdf

33. Senna BC. O estabelecimento da filiação na lei de procriação medicamente assistida portuguesa. Rev. Eletrônica de Direito [internet]. 2017 [acesso em 20 de abril de 2020]; 4(5):70-95. Disponível em: http://revistasfap.com/ojs3/index.php/direito/article/view/37

34. Argentina. Proyecto de Código Civil y Comercial de la Nación. Infojus; 2012 [acesso em 20 de abril de 2020]. Disponível em: http://www.bibliotecadigital. gob.ar/items/show/1522

35. Argentina. Ley 26.994/2014. Código Civil y Comercial de 07/10/2014. Infoleg; 2014 [acesso em 20 de abril de 2020]. Disponível em: http://servicios.infoleg.gob.ar/infolegInternet/anexos/235000-239999/235975/norma.htm

36. Argentina. Proyecto de ley: Técnicas de Reproducción Humana Asistida - Expediente 4058D-2014 de 27/05/2014. Cámara de Diputados; 2014 [acesso em 20 de abril de 2020]. Disponível em: https://www.diputados.gov.ar/proyectos/proyecto. jsp?exp=4058-D-2014

37. Brasil. Resolução do CFM no 2.168/2017. Conselho Federal de Medicina. Diário Oficial da União de 10 de novembro de 2017[acesso em 20 de abril de 2020]; seção I, 73. Disponível em: https://sistemas.cfm.org.br/ normas/visualizar/resolucoes/BR/2017/2168

38. Brasil. Lei no 10.406/2002. Código Civil de 10/01/2002. Diário Oficial da União de 11 de janeiro de 2002 [acesso em 20 de abril de 2020]; seção I. Disponível em: http://www.planalto.gov.br/ccivil_03/leis/2002/110406.htm

39. Colômbia. Proyecto de Ley 151/2001. Modificación del Código Civil y Penal referente a la aplicación de los métodos de procreación humana asistida. Gaceta del Congreso. 2001 [acesso em 20 de abril de 2020]; no 558. Disponível em: http://svrpubindc.imprenta.gov.co/senado/index 2 . xhtml?ent $=$ Senado $\&$ fec $=06-11-2001 \&$ num $=558$ 
40. Colômbia. Ley 57/1887. Código Civil Colombiano. Congreso de la República de Colombia; 1887 [acesso em 20 de abril de 2020]. Disponível em: https://www.funcionpublica.gov.co/eva/gestornormativo/norma.php?i=39535

41. Espanha. Ley 14/2006. Sobre técnicas de reprodução humana assistida de 26/05/2006. Boletín Oficial del Estado de 27 de mayo de 2006 [acesso em 20 de abril de 2020]; $\mathrm{n}^{\circ} 126$. Disponível em: https://www.boe.es/buscar/act.php?i$\mathrm{d}=$ BOE-A-2006-9292

42. Espanha. Constitución española de 31/10/1978. Boletín Oficial del Estado de 29 de diciembre de 1978 [acesso em 20 de abril de 2020]; $\mathrm{n}^{\circ} 311$. Disponível em: https://www.boe.es/buscar/doc.php? id=BOE-A-1978-31229

43. Peru. Anteproyecto de Reforma del Código Civil Peruano. Grupo de Trabajo Revisión y Mejoras Código Civil Peruano de 1984. La Ley; 2019 [acesso em 20 de abril de 2020]. Disponível em: https://laley.pe/art/8446/este-es-el-anteproyecto-de-reforma-del-codigo-civil-descargue-el-texto

44. Peru. Decreto Legislativo $\mathrm{n}^{\circ}$ 295. Código Civil del Perú de 24/06/1984. Congreso de la República; 1984 [acesso em 20 de abril de 2020]. Disponível em: http://spij.minjus.gob.pe/notificacion/guias/ CODIGO-CIVIL.pdf

45. Portugal. Lei 32/2006. Regula as Técnicas de reprodução medicamente assistida de 26/07/2006. Diário da República de 26 de julho de 2006 [acesso em 20 de abril de 2020]; $1^{\text {a }}$ Série, $\mathrm{n}^{\circ}$ 143. Disponível em: http://www.pgdlisboa.pt/leis/lei_mostra_articulado. php?nid=903\&tabela=leis

46. Uruguai. Ley $\mathrm{n}^{\circ} 19.167$ sobre Técnicas de Reproducción Humana Asistida de 22/11/2013. Diario Oficial de 29 de noviembre de 2013 [acesso em 20 de abril de 2020]; no 28854. Disponível em: https://legislativo.parlamento.gub.uy/temporales/ leytemp6434838.htm

47. Uruguai. Ley no 16.603 Código Civil de 19/10/1994. Diario Oficial de 21 de noviembre de 1994 [acesso em 20 de abril de 2020]; n 24177. Disponível em: https:// www.impo.com.uy/bases/codigo-civil/16603-1994

48. Dostal J et al. Post-mortem sperm retrieval in new European Union countries: Case report. Hum Reprod [internet]. 2005;20(8):2359-61. htpp://dx.doi.org/10.1093/ humrep/dei026
49. Batzer FR, Hurwitz JM, Caplan A. Postmortem parenthood and the need for a protocol with posthumous sperm procurement. Fertil Steril [internet]. 2003;79(6): 1263-69. http://dx.doi.org/10.1016/ S0015-0282(03)00384-4

50. Bahadur G. Death and conception. Hum Reprod [internet]. 2002;17(10):2769-75. htpp://dx.doi.org/10.1093/ humrep/17.10.2769

51. Stoker M, Landry A. The ethics of a postmortem testicular harvest. J Emerg Med [Internet]. 2016;50(1):17880. htpp://dx.doi.org/10.1016/j.jemermed.2015.09.020

52. Waler NJ et al. Policy on posthumous sperm retrieval: Survey of 75 Major Academic Medical Centers. Urology [internet]. 2018;113:45-51. htpp://dx.doi.org/ 10.1016/j.urology.2017.10.048

53. Pajot E, Muñoz Sastre MT, Mullet E. Mapping French people's views regarding posthumous reproduction. J Reprod Infant Psychol [internet]. 2017;35(5):524-37. htpp://dx.doi.org/10.1080/02646838.2017.1371283 